Tér és Társadalom 19. évf. 2005/3-4. 223-226. p.

Tér és Társadalom

XIX. évf. 2005

$3-4: 223-236$

\title{
KÖNYVJELZÖ
}

\section{ERDŐSI FERENC: MAGYARORSZÁG KÖZLEKEDÉSI- ÉS TÁVKÖZLÉSI FÖLDRAJZA}

\author{
(Dialóg Campus Kiadó, Budapest-Pécs, 2005, 504 o.)
}

\section{LIESZKOVSZKY JÓZSEF}

Igen nagy megtiszteltetés számomra, hogy Erdösi Ferenc legújabb könyvéröl amely Magyarország közlekedési- és távközlési földrajza címet viseli - készíthetek recenziót.

A könyvben két fontos téma kerül tárgyalásra, egyik hazánk közlekedése, másik pedig az infokommunikáció-telekommunikáció magyarországi helyzete.

A szerzỏ már a bevezetésben ismerteti a gazdaságföldrajz ezen két ágának kapcsolatát: „A közlekedés és a távközlés ma már nem csupán a többi ágazat kiszolgálója, hanem egyre inkább a gazdasági-társadalmi folyamatok vezérlỏ múvének szerepét is betöltve olyan önálló ágazattá nỏtte ki magát, amely a gazdasági növekedésben nagyra értékelt húzóágazatként a kommunikációs behálózottsággal Magyarországon is lehetövé teszi a mobil, illetve az információs társadalom kialakulását."

A bevezetést követően az I. részben a közlekedés fejlödésének rendszerváltást követö eseményeiröl ír a szerző, mint a közlekedés és a távközlés felértékelödése, illetve a közlekedés alágazati szerkezete. A fejezet végén megállapításra kerủl az, hogy hazánk közlekedése sokkal jobban el van maradva a fejlett gazdaságú országok közlekedésétól, mint azt a korábbi kutatások kimutatták.

A II. részben a közlekedési alágazatok fejlődésének területi sajátosságairól esik szó, a közlekedés szállítási módjai szerint csoportosítva (vasúti, közúti, vízi, légi közlekedés, valamint a logisztika és kombinált áruszállítás).

A vasúti közlekedés alfejezet - korábbi szokásoktól eltéröen - nem történeti felvezetéssel kezdődik, hanem a lehetséges fejlesztések bemutatásával. Ebben a szakaszban a Helsinki és TINA-folyosók magyarországi hatásairól, valamint az elmúlt években hazánkban végzett nemzetközi jelentőségü pályaépítési beruházásokról (nevezetesen az új magyar-szlovén vasútvonal, illetve a Budapest-Hegyeshalom vonal nagy sebességú pályává való átalakításáról) tudhatunk meg újabb információkat.

A vasúti személyforgalom települési jellemzői között kiemelt helyen szerepel az InterCity és InterPicy szolgáltatások bemutatása. Az InterCityk az egykori 1-3 köztes megállóval rendelkezô, fövárosból induló sugárirányú gyorsvonatokból fejlödtek ki, első „,megjelenésük” 1991-ben volt a Budapest-Miskolc vasútvonalon, az InterPicy hálózaton pedig (az IC-k kisegítésére motorvonatokkal) a közlekedés 1997-ben indult meg. Jelenleg az IC/IP hálózatba 96 település van bekapcsolva. 
Örömömre, a napi sajtóban is igencsak aktuális téma, az elővárosi vasúti közlekedés kialakítására irányuló lépések is ismertetésre kerülnek ebben a fejezetben, kiemelve az agglomeráción belüli átlós vasúti (pl.: Vác-Monor) szolgáltatások kialakításának fontosságát.

A vasúti-teheráruforgalom rendszerváltást követő hanyatlása (a vasúti áruszállítás a GDP-nél kétszer gyorsabban esett vissza!), és a szállítmányszerkezet átalakulása (pl.: nincs darabáru-szállítás) ugyancsak fontos része az alfejezetnek.

A vasúti közlekedés alfejezet végén a keskeny nyomtávú vasutakról is olvashatunk, amelyek egy része hivatásforgalmat lát el, a másik - a nagyobb - részük pedig turisztikai és erdészeti igényeket szolgál ki.

Sorrendben ugyan nem a következő, de a másik fontos alfejezet (a II. részen belül) a közúti közlekedés, amelyben elsőként hazánk közúthálózatának minőségéről, valamint a hálózat geometriai sajátosságairól esik szó.

A közúthálózathoz szervesen kapcsolódik a gépjármủállomány. Ismeretes, hogy a személygépkocsi-ellátottság települési jellemzői szoros kapcsolatot mutatnak az adott település/térség gazdasági fejlettségével, viszont a nagyvárosi autóellátottság a hagyományos képpel szemben mást mutat (Pl: Nyíregyháza fajlagos gépkocsiellátottsága magasabb, mint Szegedé. Véleményem szerint itt a fö ok a két város eltérő minőségủ helyi közforgalmú közlekedésében keresendő.)

A szerző böségesen ír a könyv talán legaktuálisabb és a jelen kormányzat által leginkább preferált közlekedési fejlesztéséről, az autópályák fejlesztési lehetőségeiröl. Az autópálya-nyomvonalak tervezése során kívánatos lenne a transzverzális irányú vonalak előtérbe helyezése a rendszer sugárirányúságának oldása végett. Azonban ilyen irányú vonalak megépítése csak középtávú célként szerepel (M9). A jövőbeni autópálya-fejlesztéseket összegezve a 39. táblázatban találhatjuk.

A könyv egyik érdekessége Magyarország jelenlegi víziközlekedésének, folyami hajózásának részletes bemutatása és a lehetséges továbblépés felvázolása. Hazánk víziúthálózata európai viszonylatban az átlagosnál sủrübbnek mondható, kihasználtsága viszont jóval elmarad a sürü hálózat adta lehetőségektöl. Ennek egyik oka a vízi utaink hihetetlen rossz állapota, továbbá hazánk kikötőinek teljesítőképessége is nagyon elmarad az általános és átlagos EU-s viszonyoktól. További sajnálatos esemény volt a teljes magyar tengerhajózás 2000-ben történő felszámolása. A belvízi hajózás - a Balatonon - kezdettől fogva a turizmust szolgálta, míg a folyami személyhajózás valaha közforgalmú (BKV kishajószolgálat) szerepet is betöltött a Dunán, manapság azonban ott is inkább a turisztikai szempontok a dominánsak (szárnyashajó, luxus szállodahajózás).

Hazánk légi közlekedésének tárgyalása során elsőként Ferihegyről ír a szerzö; magáról a repülőtérről, a terminál bővítésének okairól, valamint a városközponttal történő kötöttpályás tömegközlekedési kapcsolatok (metró vagy a vasúti fővonalból való kiágazás) lehetséges megvalósulásairól. Felteszi a kérdést, hogy Budapest (Ferihegy) képes lesz-e Közép-Kelet-Európa kapujává válni a már számtalan Délés Közép-Amerikából, valamint Távol-Keletröl érkező gépeket fogadó Bécs (Schwechat) mellett. Ezenfelül kitér vidéki repülötereink területfejlesztő hatásaira 
Tér és Társadalom 19. évf. 2005/3-4. 223-236. p.

is. Egy regionális repülőtér csak akkor képes színvonalasan kiszolgálni a régioót, ha gyors elérhetőségét jó közúti kapcsolatok biztosítják.

A mú 3. részében Magyarország közlekedésének föbb térreleváns kérdéseiröl olvashatunk, - elsöként az európai közlekedési térben elfoglalt szerepünkröl, amelyben hazánk közlekedési térben elfoglalt helyzetéröl, illetve a nemzetközi személyközlekedési rendszerekröl kapunk újabb információkat (tervezett nagysebességủ vasutak vagy a légiközlekedés által teremtett térkapcsolatok).

Ezen 3. részben elkerülhetetlen hazánk közlekedési hálózatának egyközpontúságára is kitérni; a szerzö a történelmi gyökerek rövid ismertetését követően rátér az egyközpontúság oldása érdekében tett lépések elégtelenségéről. Fő problémaként az említi, ....hogy a transzverzálisok megépülésére akkor kerül sor, ha a sugaras rendszerrel szemben már képtelenek igazi térszerkezet-alakító eróként funkcionálni."

A megoldás mindenféleképp az lenne, ha valamilyen módon decentralizált modellt (sugaras-gyürüs szerkezet) hoznának létre, amire a könyvben több példát is felhoz (pl.: Fleischer-féle levélboríték-modell).

Az EU-ba való belépésünkkor felértékelödött a határok szerepe, ehhez kapcsolódik az államhatárok átjárhatósága alfejezet, amelyben képet kaphatunk a határszakaszaink személy- és áruforgalmáról. A találó nevü híd- és kompföldrajz részben a hidainkról és a magyar kompszolgáltatásokról olvashatunk (A kompforgalom teljesítménye a hidaknak csak az $1 \%$-át teszi ki!). Szemléletes a könyv 71. ábrája, amiröl látható az, hogy a Duna alsó szakasza mind hidak, mind a kompösszeköttetések számában igencsak hiányt szenved. A szélesnyomtávú vasutak kedvelöinek igencsak tetszhet a 69. ábra, amely a záhonyi átrakókörzetet térségét mutatja.

Számomra az egyik legérdekesebb fejezet a „Hazánk vidéki térségeinek közlekedési ellátottsága" címet viseli. Ebben elsőként a mellékúthálózat szerepéről kaphatunk képet, majd a vasúti mellékvonalak problematikájáról. A Vasutasok Szakszervezete által a szerző rendelkezésére bocsátott 84 . ábra jól mutatja, hogy melyek azok a vonalak, amelyeket a MÁV Rt. az - ,szép szavakkal kifejezve” - tizemeltetési köréből ki akarja vonni. Az elmúlt évtizedekben a legnagyobb méretú vasútmegszüntetés Belső-Somogyban történt, ahol 5 év leforgás alatt 3 vonal szünt meg. Ezzel Kaposvár megyén belüli vasúti összeköttetései igencsak lecsökkentek (Megszünt a vasúti kapcsolat a megye legiparosodottabb kisvárosával, Barccsal, ami a város hosszútávú fejlödésében igencsak kedvezötlen eredményeket hozott).

A falusi térségek autóbusz-közlekedésének problémái ugyanolyan fontosak, mint a vasúti problémák (A zsákfalvakba sok esetben feleslegesen betérö karácsonyfajáratok nagy veszteséget hoznak a Volán társaságoknak). Erre megoldásként szolgálhat az igényvezérelt tömegközlekedési rendszerek elterjesztése.

Érdekességként megemlíthető az a nem annyira köztudott tény, hogy vannak olyan települések, amelyek azért nincsenek bekapcsolva a Volán autóbuszhálózatba, mert a vasúti kapcsolatuk kifejezetten jónak mondható. Ezek a települések nagyobb számban nem a fỏváros környékén találhatók, hanem a NyíregyházaZáhony vasútvonal mentén (Fényeslitke, Komoró). 
Az utolsó alfejezetben a közlekedésnek a térségi fejlődésre gyakorolt hatásait taglalja Erdösi Professzor Úr az autópályák gazdasági hatásai példáján. Az infrastruktúra-fejlesztések igen fontosak a periférikus térségek felzárkóztatása során, de ezek önmagukban hatástalanok. A közlekedés igazán csak akkor tudja a gazdaságot egy adott területen dinamizálni, ha a gazdaság ahhoz megfelelö színvonalon van. Tehát nem érdemes rövidtávon „csodákat várni” az autópályáktól.

A könyv másik fontos témája a távközlés és az infokommunikáció. A rendszerváltást követően a vezetékes hálózatba bekapcsolt lakások aránya folyamatosan nött, a mobilkészülékek száma viszont robbanásszerüen ugrott meg a 2000-2002 közötti időszakban. Az ISDN és ADSL ellátottság mutatóiban még napjaikban is erős területi különbségek figyelhetök meg.

Az infokommunikáció fejezet hazánk számítógép-ellátottságával foglalkozik, ezen kívül pedig a domain-név regisztrációkról valamint a felsöoktatásban használt HBONE-hálózatokról is olvashatunk.

A könyv összességében új szempontok szerint mutatja be a közlekedést és a távközlést, több, az eddigi földrajzkönyvekböl hiányzó témákat is tartalmaz (infokommunikáció, a közlekedés térreleváns kérdései). A könyv további nagy jelentősége az, hogy számos aktuális információt tartalmaz. Egyszerre könnyen érthetö és tudományos jellegü, azaz mind a szakmabeli, mind a nem szakmabeli olvasók örömmel forgathatják. 